\title{
MODEL PEMBELAJARAN PAIKEM TIPE LOGAN AVENUE PROBLEM SOLVING (LAPS)- HEURISTIC TERHADAP HASIL BELAJAR PESERTA DIDIK
}

\author{
Rizna Tri Ayuni' ${ }^{1}$, llah ${ }^{2}$, Ahyo Ruhyanto ${ }^{3}$ \\ 1,2,3 Program Studi Pendidikan Akuntansi, Universitas Galuh, Jl. R. E. Martadinata No.150, Ciamis, Indonesia \\ Email: riznata6@gmail.com,llahmulyadi.im@gmail.com
}

\begin{abstract}
The purpose of this research was to find out: (1) The differences in student learning outcomes using the Logan Avenue Problem Solving (LAPS)-Heuristic PAIKEM learning model in the pretest and posttest in the experimental class. (2) Differences in student learning outcomes using conventional learning methods in the pretest and posttest in the control class. (3) Differences in student learning outcomes using the PAIKEM learning model Logan Avenue Problem Solving (LAPS)-Heuristic with those using conventional learning methods in the final measurement (posttest). The method used in this research is an experimental method with a Quasi Experimental Non-equivalent Control Group Design. The results showed that: (1) There were differences in student learning outcomes using the Logan Avenue Problem Solving (LAPS)Heuristic PAIKEM Learning Model in the pretest and posttest. (2) There are differences in student learning outcomes using Conventional Learning Methods in the initial measurement (pretest) and the final measurement (posttest). (3) There are differences in student learning outcomes using the PAIKEM Learning Model Logan Avenue Problem Solving (LAPS)-Heuristic with those using the Conventional Learning Method in the final measurement (posttest).
\end{abstract}

Keywords: Logan Avenue Problem Solving (LAPS)- Heuristic Methods, Learning Outcomes

\begin{abstract}
ABSTRAK
Tujuan penelitian ini dilakukan untuk mengetahui: (1) Perbedaan hasil belajar peserta didik yang menggunakan model pembelajaran PAIKEM Tipe Logan Avenue Problem Solving (LAPS)-Heuristic pada pengukuran awal (pretest) dan pengukuran akhir (posttest) di kelas eksperimen. (2) Perbedaan hasil belajar peserta didik yang menggunakan metode pembelajaran konvensional pada pengukuran awal (pretest) dan pengukuran akhir (posttest) di kelas kontrol. (3) Perbedaan hasil belajar peserta didik yang menggunakan model pembelajaran PAIKEM Tipe Logan Avenue Problem Solving (LAPS)- Heuristic dengan yang menggunakan metode pembelajaran konvensional pada pengukuran akhir (posttest). Metode yang digunakan dalam penelitian ini yaitu metode eksperimen dengan desain Quasi Eksperimental Non-equivalent Conrol Group Design. Hasil penelitian menunjukkan bahwa: (1) Terdapat perbedaan hasil belajar peserta didik yang menggunakan Model Pembelajaran PAIKEM Tipe Logan Avenue Problem Solving (LAPS)- Heuristic pada pengukuran awal (pretest) dan pengukuran akhir (posttest). (2) Terdapat perbedaan hasil belajar peserta didik yang menggunakan Metode Pembelajaran Konvensional pada pengukuran awal (pretest) dan pengukuran akhir (posttest). (3) Terdapat perbedaan hasil belajar peserta didik yang menggunakan Model Pembelajaran PAIKEM Tipe Logan Avenue Problem Solving (LAPS)- Heuristic dengan yang menggunakan Metode Pembelajaran Konvensional pada pengukuran akhir (posttest).
\end{abstract}

Kata Kunci: Metode Pembelajaran Logan Avenue Problem Solving (LAPS)- Heuristic, Hasil Belajar

Cara sitasi: Ayuni, T. R., Ilah., \& Ruhyanto, A. (2021). Model Pembelajaran PAIKEM Tipe Logan Avenue Problem Solving (LAPS) Heuristic Terhadap Hasil Belajar Peserta Didik. J-KIP (Jurnal Keguruan dan IImu Pendidikan), 2 (3), 77-86. 


\section{PENDAHULUAN}

Dalam pendidikan nasional, belajar merupakan suatu proses yang terjadi pada diri setiap individu sehingga dapat menimbulkan perubahan tingkah laku pada diri setiap individu tersebut. Proses pembelajaran di sekolah dilaksanakan secara terencana dan diarahkan untuk terjadinya perubahan pada diri siswa baik dalam aspek kognitif, afektif, maupun psikomotor. Menurut Tari, Suwirta \& Dedeh (2020) menyatakan belajar itu sendiri merupakan suatu proses dari seseorang yang berusaha memperoleh suatu bentuk perubahan perilaku yang relatif menetap. Dalam kegiatan pembelajaran atau kegiatan intruksional, biasanya pendidik menetapkan tujuan belajar. Peserta didik yang berhasil dalam belajar adalah yang berhasil mencapai tujuan-tujuan pembelajaran atau tujuan intruksional. Oleh karena itu hasil belajar merupakan salah satu tolak ukur untuk mengetahui keberhasilan belajar peserta didik. Semakin baik nilai hasil belajar peserta didik, maka pembelajaran tersebut dapat dikatakan semakin berhasil.

Hasil belajar merupakan kemampuan yang diperoleh individu setelah proses belajar berlangsung, yang dapat memberikan perubahan tingkah laku baik pengetahuan, pemahaman, sikap dan keterampilan peserta didik sehingga menjadi lebih baik dari sebelumnya. Hal ini sejalan dengan pendapat Rusman (Pramudya et al., 2019) "Hasil belajar adalah sejumlah pengalaman yang diperoleh siswa yang mencakup ranah kognitif, afektif, dan psikomotorik".

Keberhasilan siswa dalam tes ditentukan dengan standar minimum nilai atau Kriteria Ketuntasan Minimal (KKM) mata pelajaran. Apabila nilai yang diperoleh siswa berada di atas kriteria tersebut maka siswa dinyatakan tuntas. Namun sebaliknya bila nilainya lebih rendah dari kriteria tersebut maka siswa dinyatakan belum tuntas. Dengan demikian Kriteria Ketuntasan Minimal (KKM) yang tinggi seharusnya membangun motivasi siswa untuk lebih giat belajar dan pada akhirnya akan menghasilkan nilai belajar yang memuaskan dengan kata lain, hasil belajar siswa akan baik pula.

Pada kenyataannya hasil belajar peserta didik di sekolah tidak seluruhnya berada diatas kriteria ditentukan. Banyak peserta didik yang hasil belajarnya rendah dan harus memperbaiki nilai belajarnya melalui remedial. Hasil belajar yang rendah mengindikasikan pemahaman peserta didik yang rendah terhadap materi pembelajaran yang mereka pelajari. Hasil belajar yang rendah ini dapat disebabkan oleh beberapa faktor seperti; latar belakang dan motivasi peserta didik itu sendiri, sarana belajar yang kurang memadai, maupun faktor pendidik dalam menyampaikan materi ajar.

Berdasarkan data awal yang diperoleh dari SMA Negeri 1 Pamarican menunjukan bahwa hasil belajar peserta didik pada mata pelajaran ekonomi masih rendah. Banyak penyebab rendahnya tingkat hasil belajar peserta didik diantaranya yaitu kondisi peserta didik seperti kurangnya motivasi dalam belajar, dan faktor pendidik pada umumnya sibuk dalam segala administrasi sehingga pendidik lebih sering menggunakan metode pembelajaran konvensional yang lebih banyak mengandalkan ceramah, maka akan membuat peserta didik cenderung pasif, mudah jenuh, dan informasi yang tertangkap oleh peserta didik tidak sesuai dan tidak memecahkan masalah tentang materi pembelajaran.

Selanjutnya dibawah ini disajikan tabel salah satu nilai ulangan harian pada mata pelajaran ekonomi semester ganjil kelas X IPS SMA Negeri 1 Pamarican tahun ajaran 2020/2021.

Tabel 1. Nilai Ulangan Harian Mata Pelajaran Ekonomi

Kelas X IPS SMA Negeri 1 Pamarican 2020/2021

\begin{tabular}{|c|c|c|c|c|c|c|c|c|}
\hline \multirow[t]{2}{*}{ Kelas } & \multirow[t]{2}{*}{ KKM } & \multirow{2}{*}{\multicolumn{2}{|c|}{$\begin{array}{c}\text { Nilai } \\
\text { Terendah Tertinggi }\end{array}$}} & \multirow{2}{*}{ Nilai Rata-Rata } & \multicolumn{2}{|c|}{ Mencapai KKM } & \multicolumn{2}{|c|}{ Belum Mencapai KKM } \\
\hline & & & & & Jumlah & $\%$ & Jumlah & $\%$ \\
\hline XIPS- & 75 & 72 & 88 & 75,12 & 16 & 47,06 & 18 & 52,94 \\
\hline XIPS- & 75 & 70 & 80 & 74,50 & 15 & 46,88 & 17 & 53,12 \\
\hline X IPS- & 75 & 70 & 80 & 74,31 & 15 & 46,88 & 17 & 53,12 \\
\hline
\end{tabular}

Sumber: SMA Negeri 1 Pamarican 2020/2021 
Berdasarkan tabel 1, peserta didik belum atau pun masih kurang paham tentang materi ekonomi, hal ini disebabkan karena metode pembelajaran yang digunakan guru dalam kegiatan pembelajaran kurang memberikan akses untuk lebih mengembangkan pola pikir peserta didik.

Salah satu upaya untuk mengatasi masalah yang ada dan meningkatkan hasil belajar yaitu dengan menggunakan model pembelajaran PAIKEM Tipe Logan Avenue Problem Solving (LAPS)Heuristic. Logan Avenue Problem Solving (LAPS)-Heuristic mempunyai tujuan dan kelebihan yaitu memungkinkan peserta didik belajar lebih aktif, karena memberikan kesempatan mengembangkan diri, fokus pada pemecahan masalah. Menurut Adiarta (dalam Rahman, Murnaka \& Wiyanti, 2018) "Metode pembelajaran LAPS-Heuristik merupakan salah satu metode pembelajaran yang berpusat pada siswa (student center). Pada metode ini siswa dituntun untuk menyelesaikan permasalahan dengan memahami terlebih dahulu apa masalahnya, adakah alternatifnya, apakah bermanfaat, apakah solusinya, dan bagaimana sebaiknya cara mengerjakannya".

Menurut Aryansyah (2021) Penerapan metode pembelajaran yang diterapkan oleh pendidik dalam proses pembelajaran sangat berpengaruh terhadap berhasil tidaknya kegiatan pembelajaran. Hal ini sejalan dengan penelitian sebelumnya (Wahyuni, 2015) dengan hasil penelitian "Pengembangan Karakter Kedisiplinan Dan Kemampuan Pemecahan Masalah Melalui Model Laps Heuristik Materi Lingkaran kelas VIII". Dari penelitian sebelumnya terdapat perbedaan cara meningkatkan hasil belajar peserta didik. Di penelitian sebelumnya metode Logan Avenue Problem Solving (LAPS)- Heuristic difokuskan untuk mengembangkan karakter kedisiplinan dan kemampuan pemecahan masalah sedangkan dalam penelitian ini, metode Logan Avenue Problem Solving (LAPS)- Heuristic bukan hanya untuk mengembangkan karakter kedisiplinan dan kemampuan pemecahan masalah namun juga meningkatkan hasil belajar peserta didik.

Penelitian ini bertujuan untuk :

1. Perbedaan hasil belajar peserta didik yang menggunakan model pembelajaran PAIKEM Tipe Logan Avenue Problem Solving (LAPS)-Heuristic pada pengukuran awal (pretest) dan pengukuran akhir (posttest) di kelas eksperimen.

2. Perbedaan hasil belajar peserta didik yang menggunakan metode pembelajaran konvensional pada pengukuran awal (pretest) dan pengukuran akhir (posttest) di kelas kontrol.

3. Perbedaan hasil belajar peserta didik yang menggunakan model pembelajaran PAIKEM Tipe Logan Avenue Problem Solving (LAPS)- Heuristic dengan yang menggunakan metode pembelajaran konvensional pada pengukuran akhir (posttest).

Hipotesis pada penelitian ini yaitu :

1. Terdapat perbedaan hasil belajar peserta didik yang menggunakan model pembelajaran PAIKEM Tipe Logan Avenue Problem Solving (LAPS)- Heuristic pada pengukuran awal (pretest) dan pengukuran akhir (posttest) di kelas eksperimen.

2. Terdapat perbedaan hasil belajar peserta didik yang menggunakan metode pembelajaran konvensional pada pengukuran awal (pretest) dan pengukuran akhir (posttest) di kelas kontrol.

3. Terdapat perbedaan hasil belajar peserta didik yang menggunakan model pembelajaran PAIKEM Tipe Logan Avenue Problem Solving (LAPS)- Heuristic dengan yang menggunakan metode pembelajaran konvensional pada pengukuran akhir (posttest).

\section{METODE PENELITIAN}

Metode yang digunakan dalam penelitian ini adalah metode quasi eksperimental design. Desain penelitian yang akan digunakan oleh peneliti adalah Nonequivalent Control Group Design. 
Tabel 2. Tabel Non-equivalent Control Group Design

\begin{tabular}{cccc}
\hline Kelas & Pretest & Perlakuan & Posttest \\
\hline Eksperimen & $\mathrm{O}_{1}$ & $\mathrm{X}$ & $\mathrm{O}_{2}$ \\
Kontrol & $\mathrm{O}_{3}$ & & $\mathrm{O}_{4}$ \\
\hline
\end{tabular}

Keterangan:

(Lestari \& Yudhanegara, 2015)

$\mathrm{O}_{1}$ : Pre test kelas eksperimen

$\mathrm{O}_{2}:$ Post test kelas eksperimen

$\mathrm{O}_{3}:$ Pre test kelas kontrol

$\mathrm{O}_{4}$ : Post test kelas kontrol

$X$ : Perlakuan (treatment) dengan menggunakan model pembelajaran PAIKEM Tipe Logan Avenue Problem Solving (LAPS)-Heuristic.

\section{Populasi}

Populasi dalam penelitian ini adalah peserta didik kelas X IPS SMA Negeri 1 Pamarican tahun ajaran 2020/2021, sebanyak 3 kelas dengan jumlah peserta didik 98 peserta didik.

Tabel 3. Populasi Peserta Didik

\begin{tabular}{ccc}
\hline No & Kelas & Populasi Peserta Didik \\
\hline 1 & X IPS 1 & 34 \\
2 & X IPS 2 & 32 \\
3 & X IPS 3 & 32 \\
\hline
\end{tabular}

Sumber : SMAN 1 Pamarican

\section{Sampel}

Teknik pengambilan sampel yang dilakukan oleh penulis dalam penelitian ini adalah menggunakan teknik nonprobability sampling. Salah satu teknik sampling yang akan digunakan oleh penulis dari nonprobablity sampling adalah purposive sampling.

Dalam penelitian ini, sampel diambil sebanyak 64 orang yang terdiri dari 32 orang kelas $X$ IPS 2 sebagai kelas eksperimen, dan 32 orang kelas X IPS 3 sebagai kelas kontrol.

\section{HASIL DAN PEMBAHASAN}

Perbedaan Hasil Belajar Peserta Didik yang Menggunakan Model Pembelajaran PAIKEM Tipe Logan Avenue Problem Solving (LAPS)- Heuristic pada Pengukuran Awal (Pretest) dan Pengukuran Akhir (Posttest)

Berdasarkan hasil penelitian menunjukkan bahwa terdapat perbedaan hasil belajar peserta didik yang menggunakan Model Pembelajaran PAIKEM Tipe Logan Avenue Problem Solving (LAPS)- Heuristic pada pengukuran awal (pretest) dan pengukuran akhir (posttest). Pada pengukuran awal diperoleh rata-rata sebesar 51,04 dan pada pengukuran akhir diperoleh nilai ratarata sebesar 85,83 . Artinya bahwa terdapat peningkatan hasil belajar peserta didik yang signifikan dari pengukuran awal (pretest) ke pengukuran akhir (posttest) di kelas eksperimen yaitu sebesar 34,79 apabila dipersentasekan sebesar $68,16 \%$, besarnya persentase ini membuktikan bahwa penerapan model pembelajaran PAIKEM Tipe Logan Avenue Problem Solving (LAPS)- Heuristic tepat digunakan pada Mata Pelajaran Ekonomi Kompetensi Dasar Mendeskripsikan Bank Sentral, Sistem Pembayaran, dan Alat Pembayaran dalam Perekonomian Indonesia. Hal ini dikarenakan model pembelajaran PAIKEM Tipe Logan Avenue Problem Solving (LAPS)- Heuristic memiliki beberapa kelebihan yang peneliti temukan, pada saat proses pembelajaran peserta didik menjadi lebih aktif, lebih berani dalam mengungkapkan pendapat, dan dapat memecahkan masalah dalam 
pembelajaran serta suasana belajar menjadi lebih menyenangkan sehingga peserta didik dapat mengikuti jalannya pembelajaran sampai selesai.

Dalam pembelajaran yang menggunakan model pembelajaran PAIKEM Tipe Logan Avenue Problem Solving (LAPS)- Heuristic dimulai dengan penjelasan mengenai konsep pembelajaran yang akan dilakukan berkaitan dengan materi yang akan dibahas, selanjutnya guru menyampaikan materi secara garis besar, kemudian peserta didik dibagi ke dalam 4 kelompok dengan jumlah 8 orang. Setelah dibagi ke dalam kelompok, peserta didik diberikan kesempatan untuk memahami materi dan eksplor materi mengenai Bank Sentral, Sistem Pembayaran, Alat Pembayaran Tunai dan Non Tunai. Selanjutnya peserta didik akan diberikan satu materi per kelompok untuk diberikan serangkaian pertanyaan oleh guru dalam bentuk cerdas cermat untuk mengetahui sejauh mana tingkat pemahaman peserta didik. Setiap pertemuan akan dilakukan pertandingan cerdas cermat setelah selesai maka akan disimpulkan oleh masing-masing kelompok dan dikoreksi oleh guru. Selain itu peserta didik akan diberikan soal pengembangan. Sehingga peserta didik akan mengerti dan tidak mudah lupa pada materi yang sudah dipelajari. Kelompok yang memiliki nilai tertinggi akan diberikan penghargaan sebagai motivasi untuk kelompok lainnya.

Penggunaan model pembelajaran PAIKEM Tipe Logan Avenue Problem Solving (LAPS)Heuristic menuntut peserta didik untuk berperan aktif dan dapat memecahkan masalah dalam proses pembelajaran, sehingga pola pikir peserta didik akan lebih berkembang sebab pembelajaran lebih berorientasi pada peserta didik (student center), karena guru hanya berperan sebagai fasilitator. Guru sebagai fasilitator disini artinya guru harus membantu peserta didik dengan memberikan pelayanan untuk memudahkan dalam proses pembelajaran.

Beberapa hal yang mempengaruhi hasil belajar peserta didik pada pengukuran awal (pretest) sebelum diberikan perlakuan yaitu, sebagian besar pendidik tidak memberi tahu peserta didik mengenai materi pembelajaran yang akan dipelajari pada pertemuan selanjutnya, sebagian peserta didik masih tergantung kepada guru dan tidak ada keinginan untuk mencari materi pembelajaran dari berbagai sumber untuk dipelajari. Sedangkan beberapa yang mengakibatkan hasil belajar peserta didik pada pengukuran akhir (posttest) nilainya lebih tinggi setelah diberikan perlakuan yaitu dengan menggunakan metode pembelajaran Logan Avenue Problem Solving (LAPS)- Heuristic peserta didik lebih memahami materi yang dipelajari dan menjadi lebih aktif dan mandiri dalam proses kegiatan belajar mengajar.

Metode pembelajaran Logan Avenue Problem Solving (LAPS)- Heuristic merupakan rangkaian pertanyaan yang bersifat tuntutan dalam solusi masalah. Menurut Shoimin (dalam Ningsih, Husaini \& Kusnafizal, 2020) "Metode pembelajaran Logan Avenue Problem Solving (LAPS)Heuristic adalah rangkaian pertanyaan yang bersifat tuntutan dalam solusi masalah, Logan Avenue Problem Solving (LAPS)- Heuristic biasanya menggunakan kata tanya apa masalahnya, adakah alternative, apakah bermanfaat, apakah solusinya, dan bagaimana sebaiknya mengerjakannya".

Sedangkan menurut Nurdin (dalam Afidatus, 2020) menjelaskan bahwa "Heuristic adalah suatu masalah dan berfungsi mengarahkan pemecahan masalah siswa untuk menemukan solusi dari masalah yang diberikan". Jadi metode Logan Avenue Problem Solving (LAPS)- Heuristic adalah metode pembelajaran yang menuntun siswa memecahkan masalah.

Dengan demikian, metode Logan Avenue Problem Solving (LAPS)- Heuristic yaitu metode pembelajaran yang tepat digunakan untuk meningkatkan hasil belajar peserta didik.

\section{Perbedaan Hasil Belajar Peserta Didik yang Menggunakan Metode Pembelajaran Konvensional pada Pengkuran Awal (Pretest) dan Pengukuran Akhir (Posttest)}

Berdasarkan hasil penelitian menunjukkan bahwa terdapat perbedaan hasil belajar peserta didik yang menggunakan metode pembelajaran konvensional pada pengukuran awal dan pengukuran akhir mengalami perbedaan yang signifikan berdasarkan hasil uji statistik. Perbedaan 
tersebut dapat dilihat dari rata-rata nilai pada pengukuran awal diperoleh nilai rata-rata sebesar 50,83 dan pengukuran akhir diperoleh 68,54 artinya bahwa terdapat peningkatan hasil peserta didik.

Peningkatan nilai dengan selisih yaitu sebesar 17,71 atau apabila dipresentasekan sebesar 34,84 dan N-Gain 0,35 dengan kategori sedang. Hal ini menggambarkan peningkatan hasil belajar peserta didik tersebut membuktikan bahwa metode pembelajaran konvensional tepat digunakan pada Mata Pelajaran Ekonomi. Namun peningkatan prestasi belajar peserta didik belum optimal, karena dalam proses pembelajaran lebih berorientasi pada guru, dan peserta didik tidak diberikan partisipasi aktif. Oleh karena itu, peserta didik sering mengalami kejenuhan dalam belajar, sehingga pemahaman terhadap materi relatif lebih rendah. Seperti yang dikatakan Wina Sanjaya (dalam Islami \& Yondri, 2016) bahwa kelemahan metode konvensional antara lain :

1) Materi yang dapat dikuasai siswa sebagai hasil dari ceramah akan terbatas pada apa yang dikuasai guru

2) Guru yang kurang memiliki kemampuan bertutur yang baik, ceramah sering dianggap sebagai metode yang membosankan.

Adapun upaya untuk meningkatkan hasil belajar peserta didik yang menggunakan metode konvensional yaitu ketika pembelajaran di kelas pendidik harus sering melakukan tanya jawab atau berinteraksi dengan peserta didik supaya pembelajaran tidak berlangsung dengan pasif yang membuat peserta didik menjadi lebih cepat bosan dan jenuh.

Selain itu, pendidik dalam meyampaikan materi harus menggunakan bahasa yang komunikatif dan mudah dipahami oleh peserta didik dan materi yang diberikan tidak terlalu banyak serta dilakukan dengan singkat, padat, dan jelas.

\section{Perbedaan Hasil Belajar Peserta Didik yang Menggunakan Model Pembelajaran PAIKEM Tipe Logan Avenue Problem Solving (LAPS)- Heuristic dengan yang Menggunakan Metode Pembelajaran Konvensional pada Pengukuran Akhir (Posttest)}

Berdasarkan hasil penelitian menunjukkan bahwa perbedaan hasil belajar peserta didik yang menggunakan model pembelajaran PAIKEM Tipe Logan Avenue Problem Solving (LAPS)- Heuristic lebih tinggi dibandingkan hasil belajar peserta didik yang menggunakan metode pembelajaran konvensional. Hal ini dapat dilihat dari hasil rata-rata nilai yang diperoleh peserta didik pada pengukuran akhir (posttest) yaitu nilai rata-rata pengukuran akhir yang menggunakan model pembelajaran PAIKEM Tipe Logan Avenue Problem Solving (LAPS)- Heuristic diperoleh rata-rata nilai sebesar 85,83 dengan $\mathrm{N}$-Gain sebesar 0,72 dan pengukuran akhir yang menggunaka metode konvensional diperoleh rata-rata nilai sebesar 68,54 dengan $\mathrm{N}$-Gain sebesar 0,35. Hal ini menunjukkan bahwa nilai rata-rata pada pengukuran akhir di kelas yang menggunakan model pembelajaran PAIKEM Tipe Logan Avenue Problem Solving (LAPS)- Heuristic lebih besar dibandingkan dengan nilai rata-rata di kelas yang menggunakan metode pembelajaran konvensional, begitu juga N-Gain di kelas eksperimen lebih besar dibandingkan dengan N-Gain di kelas kontrol. N-Gain di kelas yang menggunakan model pembelajaran PAIKEM Tipe Logan Avenue Problem Solving (LAPS)- Heuristic berkategori tinggi dan N-Gain di kelas yang menggunakan metode pembelajaran konvensional berkategori sedang. Artinya model pembelajaran PAIKEM Tipe Logan Avenue Problem Solving (LAPS)- Heuristic lebih unggul dan dapat meningkatkan hasil belajar peserta didik apabila dibandingkan dengan metode konvensional. Hal ini sesuai dengan keunggulan model pembelajaran PAIKEM Tipe Logan Avenue Problem Solving (LAPS)- Heuristic diantaranya yaitu proses pembelajaran yang berorientasi pada peserta didik (student center), sehingga peserta didik memiliki kebebasan berpendapat, lebih terampil, dan lebih aktif dalam memecahkan masalah dalam pembelajaran. Hal ini sejalan dengan teori yang dikemukakan oleh Jolife (dalam Rusman, 2017) yang menyatakn bahwa: 
"Teori belajar kontruktivisme dipelopori oleh Piaget, Bruner, dan Vygotsky pada awal abad 20an yang mempunyai pandangan bahwa pengetahuan dan pemahaman tidaklah diperoleh secara pasif akan tetapi dengan cara yang aktif melalui pengalaman personal dan aktivitas eksperimental. Konsep utama dari kontruktivisme adalah bahwa peserta didik adalah aktif untuk mencari untuk membuat pengertian tentang apa yang ia pahami. Ini berarti belajar membutuhkan untuk fokus pada skenario berbasis masalah, belajar berbasis proyek, belajar berbasis tim, stimulasi, dan penggunaan teknologi"

Penelitian ini mengacu pada teori belajar kontruktivisme, karena model pembelajaran PAIKEM Tipe Logan Avenue Problem Solving (LAPS)- Heuristic yang menekankan keaktifan kepada peserta didik dan pendidik hanya sebagai fasilitator. Selain itu aplikasi metode pembelajaran ini sama seperti aplikasi teori belajar kontruktivisme. Melalui penggunaan model pembelajaran PAIKEM Tipe Logan Avenue Problem Solving (LAPS)- Heuristic peserta didik dapat meningkatkan kemampuan dalam bekerja sama, karena keterlibatan peserta didik lebih tinggi dalam pembelajaran. Hal tersebut dapat meningkatkan semangat dalam belajar serta dapat menumbuhkan sikap positif dalam diri peserta didik. Metode pembelajaran Logan Avenue Problem Solving (LAPS)- Heuristic memberikan kemudahan bagi siswa dalam menyelesaikan suatu permasalahan, sehingga kemampuan pemecahan masalah siswa bisa lebih baik. Hal tersebut sesuai dengan pendapat Adiarta (dalam Rahman, Murnaka \& Wiyanti, 2018), bahwa:

"Metode pembelajaran LAPS-Heuristik merupakan salah satu metode pembelajaran yang berpusat pada siswa (student center). Pada metode ini siswa dituntun untuk menyelesaikan permasalahan dengan memahami terlebih dahulu apa masalahnya, adakah alternatifnya, apakah bermanfaat, apakah solusinya, dan bagaimana sebaiknya cara mengerjakannya".

Sedangkan menurut Nurdin (dalam Ningsih, Husaini \& Kusnafizal, 2020) menjelaskan bahwa "Heuristic adalah suatu penuntun berupa pertanyaan yang diperlukan untuk menyelesaikan suatu masalah dan berfungsi mengarahkan pemecahan masalah siswa untuk menemukan solusi dari masalah yang diberikan".

Temuan penelitian menunjukkan bahwa penggunaan Model Pembelajaran Tipe Logan Avenue Problem Solving (LAPS)- Heuristic dapat meningkatkan hasil belajar peserta didik. Selain itu, temuan peneliti menunjukkan bahwa Metode Pembelajaran Konvensional juga dapat meningkatkan hasil belajar peserta didik. Namun, peningkatan hasil belajar peserta didik yang menggunakan Model Pembelajaran Tipe Logan Avenue Problem Solving (LAPS)- Heuristic lebih tinggi dibandingkan dengan penggunaan Metode Pembelajaran Konvensional. Dengan demikian, temuan penelitian tersebut membuktikan bahwa semua model atau metode pembelajaran dapat meningkatkan hasil belajar peserta didik, namun berdasarkan pengalaman peneliti dalam pemilihan model atau metode pembelajaran perlu mempertimbangkan hal-hal sebagai berikut:

1) Tingkat kemampuan peserta didik

2) Karakteristik Mata Pelajaran, misalnya dalam mata pelajaran Ekonomi yang sebagian besar materi banyak yang harus dibaca dan dipahami sehingga harus diterapkan model atau metode pembelajaran yang aktif dan lebih berorientasi pada peserta didik agar peserta didik tidak merasa jenuh.

3) Fasilitas penunjang yang tersedia, karena fasilitas dan media pembelajaran dapat mendukung terlaksananya model atau metode pembelajaran.

4) Alokasi waktu, apabila waktu memungkinkan maka pendidik dapat menerapkan model atau metode pembelajaran yang memerlukan waktu relatif lebih lama.

\section{KESIMPULAN}

1. Terdapat perbedaan hasil belajar peserta didik yang menggunakan Model Pembelajaran PAIKEM Tipe Logan Avenue Problem Solving (LAPS)- Heuristic pada pengukuran awal 
(pretest) dan pengukuran akhir (posttest).

2. Terdapat perbedaan hasil belajar peserta didik yang menggunakan Metode Pembelajaran Konvensional pada pengukuran awal (pretest) dan pengukuran akhir (posttest).

3. Terdapat perbedaan hasil belajar peserta didik yang menggunakan Model Pembelajaran PAIKEM Tipe Logan Avenue Problem Solving (LAPS)- Heuristic dengan yang menggunakan Metode Pembelajaran Konvensional pada pengukuran akhir (posttest).

\section{REKOMENDASI}

Berdasarkan hasil penelitian yang telah dilakukan, penulis mengajukan beberapa rekomendasi sebagai berikut:

1. Dalam upaya meningkatkan hasil belajar peserta didik, hendaknya guru lebih mempertimbangkan secara matang dalam memilih model atau metode pembelajaran, terlebih pada saat pembelajaran daring (online).

2. Dalam penerapan Model Pembelajaran PAIKEM Tipe Logan Avenue Problem Solving (LAPS)Heuristic sebaiknya pendidik mengkombinasikan dengan model atau metode pembelajaran yang lain.

3. Bagi yang berminat melakukan penelitian lebih lanjut Model Pembelajaran PAIKEM Tipe Logan Avenue Problem Solving (LAPS)- Heuristic dapat dipilih secara alternatif, terlebih jika proses pembelajaran dilakukan secara tatap muka.

4. Bagi peneliti selanjutnya hendaknya mengkombinasikan Model Pembelajaran PAIKEM Tipe Logan Avenue Problem Solving (LAPS)- Heuristic dengan model atau metode pembelajaran yang lain serta membandingkan hasil dari penelitian tersebut.

\section{UCAPAN TERIMAKASIH}

Dalam penyusunan artikel ini tidak lepas dari berbagai hambatan dan kesulitan, namun atas

Ridho Allah SWT. Serta dorongan, bantuan, dan bimbingan dari berbagai pihak.

\section{DAFTAR PUSTAKA}

Afidatus, S. (2020). Keefektifan Model Pembelajaran Means Ends Analysis (MEA) dengan Strategi Pembelajaran Heuristik Terhadap Kemampuan Pemecahan Masalah Matematika Siswa Kelas VII SMP Negeri 2 Bringin Tahun Pelajaran 2018/2019. Other thesis, IAIN SALATIGA. http://e-repository.perpus.iainsalatiga.ac.id/7777/

Aryansyah, F. (2021). Pelaksanaan Question Student Have Method Dalam Meningkatkan Hasil Belajar Pada Mata Pelajaran Ekonomi di SMA. J-KIP (Jurnal Keguruan dan IImu Pendidikan), 2 (1), 91-98.

Islami, S., \& Yondri, S. (2016). Perbedaan Hasil Belajar Siswa Dalam Pembelajaran Kooperatif Tipe Jigsaw Dengan Konvensional. National Conference of Applied Sciences, Engineering, Business and Information Technology. Politeknik Negeri Padang, 15 - 16 Oktober 2016. https://bit.ly/3gc43XN

Lestari, K. E., \& Yudhanegara, M. R. (2015). Penelitian Pendidikan Matematika (Panduan Praktis Menyusun Skripsi, Tesis Dan Karya IImiah Dengan Pendekatan Kuantitatif, Kualitatif Dan Kombinasi Disertai Dengan Model Pembelajaran Dan Kemampuan Matematika). Bandung; PT. Refikan Aditama. 
Ningsih, D, M., Husaini., \& Kusnafizal, T. (2020). Pengembangan Kemampuan Berfikir Kritis Melalui Model Pembelajaran Logan Avenue Problem Solving (LAPS) Heuristik Pada Pembelajaran IPS Sejarah di SMP Negeri 1 Bandar Kabupaten Bener Meriah. Jurnal IImiah Mahasiswa $\begin{array}{llllll}\text { Pendidikan Sejarah Volume } 5 & \text { Nomor } & 1 & \text { (2020): }\end{array}$ http://www.jim.unsyiah.ac.id/sejarah/article/viewFile/15080/6709

Pramudya., Erviyanti., K, Firosalia., \& Anugraheni, I. (2019). Peningkatan Keaktifan dan Hasil Belajar IPA Pada Pembelajaran Tematik Menggunakan PBL. Jurnal Kajian Penelitan dan Pendidikan dan Pembelajaran Vol.3, No.2 (April 2019). file:///C:/Users/hp/Downloads/391Article\%20Text-1499-1-10-20190409.pdf

Rahman, I. S., Murnaka, N. P., \& Wiyanti, W. (2018). Pengaruh Model Pembelajaran Laps (Logan Avenue Problem Solving)-Heuristik Terhadap Kemampuan Pemecahan Masalah. Wacana $\begin{array}{llllll}\text { Akademika. } & \text { Volume } & 2 & \text { No } & 1 & \text { Tahun } \\ \end{array}$ https://pdfs.semanticscholar.org/8441/4650c09cc58d4f3717b272b8b0686841785c.pdf

Rusman. (2017). Belajar \& Pembelajaran: Berorientasi Standar Proses Pendidikan. Jakarta: Kencana.

Tari, H. D., Suwrta,U., \& Dedeh. (2020) Pengaruh Penerapan Model Pembelajaran Kooperatif Tipe Teams Games Tournament (TGT) Terhadap Hasil Belajar Peserta Didik pada Mata Pelajaran Ekonomi di MAN 2 Kota Tasikmalaya. J-KIP (Jurnal Keguruan dan IImu Pendidikan), 1 (1), 19-26.

Wahyuni, S. (2015). Pengembangan Karakter Kedisiplinan Dan Kemampuan Pemecahan Masalah Melalui Model Laps Heuristik Materi Lingkaran kelas VIII. Unnes Journal of Mathematics Education, 4(2). https://doi.org/10.15294/ujme.v4i2.7594 
